CZU:821.135.1.09

https://doi.org/10.52505/filomod.2021.15.46

\title{
EUL ADOLESCENTIN ÎNTRE RĂTĂCIRE, CĂUTARE ȘI CUNOAȘTERE
}

\author{
VIORICA ZAHARIA \\ Universitatea Pedagogică de Stat „Ion Creangă din mun. Chișinău
}

Rezumat. Plasată între copilărie sau starea pregătitoare și maturitate, vârsta rațională, adolescența, caracterizată prin schimbări fizice și frământări psihologice, este „epoca” în care începem să ne descoperim sinele original.

Vârsta formării şi marilor aspiraţii, adolescenţa este o temă literară predilectă $\hat{i n c a ̆ ~ d e ~ l a ~ i ̂ n c e p u t u r i l e ~ l i t e r a t u r i i, ~ r e z u l t a t ~ a l ~ e f o r t u l u i ~ f i n t ̧ e i ~ u m a n e ~ d e ~ a ~ s e ~ c l a r i f i c a ~ s ̧ i ~}$ impăca cu sine şi cu lumea. Odată cu literatura secolului al XX-lea, tema respectivă este exploatată la maxim, categoria ,romanelor adolescenței” fiind creată pentru a pune în evidență textele cu tematica adolescenței, subliniind statutul personajelor adolescenți, cu frământările inerente acestei vârste. Dramele existenţiale trăite de personaje adolescenţi au fost tentante şi pentru debuturile literare ale prozatorilor Mircea Eliade şi Jerome David Sallinger, creaţia cărora a influențat enorm mentalitatea societății și tinerelor generații nu doar a timpului lor.

Cuvinte-cheie: adolescență, eu adolescentin, temă literară, roman al adolescenței, Mircea Eliade, Jerome Sallinger.

Abstract. Placed between childhood and adulthood, adolescence, characterized by physical changes and psychological turmoil, is the ,age" in which we begin to discover our original self. The age of formation and great aspirations is a favorite literary theme since the beginning of literature, the result of the human being's effort to clarify and reconcile with himself and the world. With the literature of the twentieth century, the theme is fully exploited, the category of ,adolescence novels" being created to highlight texts with the theme of adolescence, emphasizing the status of adolescent characters, with the turmoil inherent in this age. The existential dramas experienced by teenage characters were also tempting for the literary debuts of the prose writers Mircea Eliade and Jerome Salinger, whose creation greatly influenced the mentality of society and the younger generations not only of their time.

Keywords: adolescence, adolescent self, literary theme, adolescence novel, Mircea Eliade, Jerome Sallinger.

Interesul sporit pentru vârsta adolescenței în secolul al XX-lea este legat și de dezvoltarea psihologiei, care definește această etapă a vieții drept o perioadă specifică, pe adolescenți percepându-i ca pe un grup social distinct, luându-se în calcul particularitățile și dificultățile tinereții. Criza economică a anilor '30, noua ordine socială postbelică, mișcările în masă a anilor '60, 
au fost provocări ce au permis adolescenților să se formeze ca grup social cu o cultură distinctă. După al doilea război mondial, în societate începe să se vorbească chiar de o cultură a adolescenței Astăzi adolescența își are propriile manifestări, propriile valori și, mai presus de orice, propria cultură; specificul ei face parte din peisajul social și cultural. Detașați de lumea adulților, adolescenții sunt conștienți de unicitatea lor ca grup. Prin urmare, frământările interioare creează un decalaj între generații și reunesc adolescenții.

Vârsta formării şi marilor aspiraţii, adolescenţa este și o temă literară predilectă încă de la începuturile literaturii, rezultat al efortului fiinţei umane de a se clarifica şi împăca cu sine şi cu lumea. La începutul mileniului al III-lea î. Hr., Epopeea lui Ghilgames, cel mai vechi text sumero-babilonian, prezintă modelul unor eroi care descoperă, în trecerea de la adolescenţă la maturitate, eterne valori umane: prietenia, devotamentul, speranţa. Literatura noastră populară, de asemenea, oferă modele ale formării prin căutarea unui ideal semnificat de cunoaşterea de sine. Astfel, basmul Tinereţe fără bătrâneţe şi viaţă fără de moarte este povestea moralizatoare a celui care, dobândind experienţe inedite, conştientizează dramatismul condiţiei umane, ca succesiune de vârste sau de etape existenţiale.

Ajungând subiect autonom în psihologie în secolul al XX-lea, adolescența va fi expluatată și cu mai mare interes de literatură. Respectiv, discursul literar despre imaturitate se schimbă, fiind mult mai autentic, mai potrivit pentru modul de comportament și pentru limbajul adolescenților. Iar categoria „romanelor adolescenței” este creată anume cu scopul de a pune în evidență textele cu tematica adolescenței, subliniind statutul personajelor adolescenți, cu frământările inerente vârstei respective. Să amintim căteva titluri semnificative pentru literatura europeană: Le Grand Meaulnes de Alain-Fournier (1913), Copiii teribili ai lui Cocteau (1965), Muntele vrăjit al lui Thomas Mann (1924) sau Rătăcirile elevului Törless de Musil (1906). Dar și câteva exemple din peisajul literar românesc al aceleiași perioade, traversat de un număr însemnat de adolescenţi din Oraşul cu salcâmi, Romanul lui Mirel, Întâmplări în realitatea imediată ș.a.m.d., cumva altfel față de predecesorii lor. Ionel Teodoreanu surprinde, în La Medeleni, vârsta-metaforă, legată de spaţiile sufleteşti ale dezvoltării. Bazându-se pe imaginea individului în formare, Mihail Sadoveanu, în Fratii Jderi, urmărește eroul în proiecţii epopeice, condiţionându-1 social şi mitic. Simţită prin trăire directă, adolescenţa devine imagine de jurnal, confesiune autentică, precum în Jurnalul de copilărie şi adolescenţă a lui Geo Bogza și exemplele ar putea continua.

În linii generale, reprezentarea adolescenților în literatură se face în două ipostaze: pe de o parte, adolescența e percepută ca cea mai fericită vârstă a vieții, unde tinerii sunt împliniți, pozitivi, avizi, responsabili, încrezători în puterile lor umane și intelectuale, iar pe de alta, această etapă este văzută ca un moment de criză al vieții, al vârstei nerecunoscătoare, când tânărul este 
răzvrătit și instabil. Adevărul este că literatura nu furnizează doar imagini pozitive ale adolescenței. Am putea chiar afirma că romanele adolescenței sunt cel mai adesea romane ale eșecului, operele De veghe în lanul de secară şi Romanul adolescentului miop fiind reprezentative în acest sens.

Aceste două romane semnificative din literatura secolului al XX-lea, rămân emblematice pentru întreaga literatură cu adolescenţi. Eroii celor două scrieri, Mircea şi Holden sunt personaje care povestesc trecerea crucială și delicată de la copilărie la vârsta adultă. Prin intermediul lor, Mircea Eliade și Jerome-David Salinger aruncă o privire critică asupra lumii, făcând din adolescență o adevărată metaforă a diferenței și contestației.

Autorul Romanului adolescentului miop, scriitorul şi savantul Mircea Eliade își publică primul roman în adolescență. Chiar dacă ulterior va fi sesizabilă diferența dintre operele tinereții și cele ale maturității literare, diversitatea tematică rămâne o dimensiune aparte a creației eliadești. Viziunea sa asupra sentimentului erotic este una pluridimensională, pornind de la dragostea pentru propria personalitate și ajungând până la dragostea pentru cunoaștere şi existență. Eliade nu deține doar un bagaj vast de cunoștințe, dar dispune și de o panoplie de experiențe trăite a aspectelor studiate.

Prezenţă discretă a peisajului artistic american, Jerome Salinger este autorul romanului De veghe în lanul de secară, identificat drept reper în categoria scrierilor ce abordează tema adolescenţei. Publicarea, în 1951, a romanului i-a asigurat lui Salinger un loc select în rândul scriitorilor interesat de tema adolescenței. Dar după succesul imediat al operei, autorul începe să-şi regrete popularitatea şi restul vieţii şi-l va învălui într-o aură de mister.

Există multe similitudini între viaţa lui Salinger şi unele evenimente descrise în operele sale. Principalele tipare, teme şi motive, precum cea a războiului şi vieţii de cazarmă, dezvoltându-se în arhetipuri uşor recognoscibile care se referă la concizia, caracterul succint și puterea de concentrare a stilului său scriitoricesc, la atenţia pe care o acordă detaliilor, datelor şi faptelor exacte. Un alt aspect important al operei lui Salinger se referă la diferenţele dintre cele două lumi în opoziţie, „lumea cu valori pozitive” şi „lumea valorilor false”, evidentă şi în motivul recurent al luptei dintre personajele reprezentative ale celor două lumi. Grăitoare sunt şi momentele de compasiune şi aspiraţii spirituale sau revelaţie, imposibile fără iubire, încredere şi/sau compasiune, toate având puterea de a salva personajele de la moartea reală sau simbolică şi oferind o perspectivă optimistă asupra existenţei.

Romanul adolescentului miop înfăţișează un adolescent oarecum atipic, dornic de a cunoaşte cât mai multe. În tumultul cunoaşterii, acesta are răgaz şi pentru problemele tipice adolescenţei, cunoaşterea de sine şi conturarea unei personalităţi. Când îşi începe jurnalul, adolescentulscriitor este un tânăr miop, nemulţumit de propria imagine fizică şi socială, inadaptat mediului, cu probleme de corigenţă la mai multe materii, dar sedus de literatura lui Balzac şi Papini, imbold pentru scrierea romanului. 
Scopul tânărului Eliade rămâne totuşi autocunoaşterea, nu prin imitarea modelelor străine, ci prin căutarea drumurilor nebătătorite, învingerea slăbiciunilor, asceză, voinţă şi descoperirea de sine.

Mansarda casei, spaţiul în care se petrece o bună parte a acţiunii romanului, plină de cărţi pe care le devorează cu nesaţ, e spaţiul de refugiu al adolescentului miop din faţa lumii exterioare ostile. Este locul unde se desfăşoară luptele interioare, călirea intelectului şi cristalizarea geniului viitorului romancier. Faptul este confirmat de nota confesivă din primul capitol, Drum către mine insumi, deoarece încercările personajului de a scrie un roman al adolescenţei autentice se vor baza pe trăiri reale adolescentine, lucru mărturisit de autorul însuşi în finalul textului. Eugen Simion nota: „Scrie în acest timp jurnalul, care se va substitui romanului, şi notează, într-o simpatică dezordine, tot ce-i trece prin minte şi i se întâmplă, fără nicio preocupare expresă pentru literatură. Dar tocmai această ignorare a literaturii dă o oarecare valoare literară acestor pagini confesive. Ele spun mult, am impresia, despre biografie tânărului Eliade şi spun ceva şi despre un posibil personaj adolescent care vrea să iasă din tiparele tradiţionale ale literaturii" (Simion, p. 235).

Mircea trăieşte drama adolescentului cu toate ispitele şi îndoielile sale. Este sincer în tot ceea ce spune, îşi aduce aminte cu exactitate experienţele trăite în liceu. Din cauza aspectului fizic, se simte complexat şi evită prieteniile. Comparându-se cu colegii care-şi etalau frumuseţea, îşi scoate în evidenţă superioritatea în gândire şi în percepţia vieţii. El întruchipează adolescentul care nu este perfect, dar înzestrat în schimb cu o gândire profundă. Pentru conturarea imaginii adolescentului miop, autorul apelează atât la autocaracterizare, cât şi la introspecţia psihologică, fapt ce subliniază ideea ca Eliade pune accentul pe modul în care autorul se vede pe el însuşi şi pe ceilalţi, şi nu pe modul în care acesta este văzut de ceilalţi. Astfel, Romanul adolescentului miop creează o imagine subtilă a problemelor sufletului juvenil şi a dramei adolescenţei cu toate ispitele şi îndoielile caracteristice.

$\mathrm{Cu}$ De veghe în lanul de secară și tânărul său narator plin de frământări interioare, Holden Caulfield, J. D. Salinger a prezentat publicului cititor imaginea personajului-adolescent cu o personalitate puternică şi carismatică. Naratorul-personaj, expulzat din școală din cauza rezultatelor academice slabe, rătăceş̧e câteva zile pe străzile New York-ului reflectând asupra menirii oamenilor și a rosturilor lumii. Deşi se manifestă mai ales sarcastic, melancolia şi, mai ales, disperarea îl însoţesc constant. Firul narativ al personajului conduce cititorul prin meandrele orașului, dar şi prin cele ale propriei minți.

Holden nu mai este copil, dar nici adult, ipostază dureroasă şi distructivă pentru el, explicată perfect de metafora veghii în lanul de secară. Își imaginează că se află pe câmpul cu secară în care copiii aleargă și se distrează, stând la marginea stâncii amenințătoare învecinată cu câmpul și se asigură ca aceştia să nu cadă în prăpastie. Vigilent și protector, este gata să-i „,prindă” dacă se poticnesc. Lanul semnifică de fapt lumea perfectă a copilăriei, pe care 
o precipită căderea în lumea adulților. Astfel, aievea lui Peter Pan, Holden încearcă să păstreze tărâmul copilăriei veșnice, misiune dificilă şi imposibilă.

Holden reprezintă întruchiparea adolescentului care suferă şi se deziluzionează de contactul cu societatea. În ciuda disperării, mai păstrează unele idealuri, o anumită naivitate, iar sensibilitatea nu-i este știrbită de dezamăgiri. Rămâne totuşi dezamăgit de trecerea timpului în general și de sfârșitul copilăriei în special, de contactul cu lumea adulţilor, ostilă, coruptă, perversă şi pierdută. Salinger a urmărit să reproducă cât mai fidel limbajul tinerilor anilor 50, motiv pentru care Holden se exprimă în termeni argotici, negramatical, cu multe expresii idiomatice. Motiv pentru care romanul a trecut prin perioade de cenzură şi interdicţii.

De veghe în lanul de secară rămâne romanul deziluziilor, pasiunilor, eforiilor, paradisurilor artificiale, crizelor, complexelor şi impedimentelor vieții. Trama narativă dă posibilitatea lectorului de a se scufunda în profunzimea chinurilor și emoțiilor, violente, mișcătoare, caracteristice acestei etape fragile și fascinante a vieții individului. O vârstă care refuză compromisurile și regulile sociale, pierderea inocenței fiind însoțită de un amestec de gust din sulf, sânge și mizerie. Totuși, în spatele întunericului și al deznădejdii se întrezărește întotdeauna un optimism infinit și căutarea sensului unei vieți luminoase, caracterizată în același timp de încăpățânare și idealism.

Mircea Eliade și Jerome Salinger au reușit să creioneze memorabil figurile a doi adolescenţi care urăsc ipocrizia, falsitatea şi oamenii lipsiţi de scrupule. Holden Caulfield este un tip inteligent și sensibil, care în cele câteva zile de hoinăreală prin New York, după plecarea de la colegiu, se cunoaşte mai bine pe sine şi realizează că are probleme grave, deoarece nu se simţea apropiat de nicio persoană din anturajul său şi nu reușește să depăşească etapele adolescenţei.

Deşi am putea afirma că în Romanul adolescentului miop suprapersonajul, şi pretext al acestui pseudojurnal, este Romanul, adolescentul rămâne naratorulpersonaj în jurul căruia se încheagă acţiunea. Adolescentul miop reprezintă tipul lectorului pasionat, care îşi ia drept model diverse personalităţi culturale. Deoarece colegii şi amicii îl tachinau că este urât, trist, slab, timid şi nehotărât, treptat el îşi va construi personalitatea prin apelul la modelele din cărţile citite. Caracterizat de unul dintre profesorii care l-au lăsat corigent drept imbecil, nu aceeaşi atitudine are şi familia, care îl susţine, nu îl ceartă şi nu îl impune să înveţe, astfel încât relaţiile cu părinţii sunt destul de bune în cazul lui Mircea. Lucru pe care nu l-am putea afirma în cazul relaţiilor părinţi-copii reflectate de romanul lui Salinger.

Ceea ce le uneşte pe cele două personaje emblematice pentru literatura cu adolescenţi este faptul că Mircea şi Holden, aflaţi la vârsta critică a nesiguranțelor şi căutărilor, nutresc să plece de acasă, se revoltă împotriva lumii adulţilor şi visează să schimbe lumea şi societatea. Amândoi întâmpină probleme la şcoală. Trec prin experienţa corigenţelor nu pentru că nu ar fi 
inteligenţi, ci pentru că au alte preocupări sau resping şcoala în semn de revoltă. Îi deosebeşte însă situaţia financiară, Holden având o situaţie financiară bună şi studiind la şcoli private, iar adolescentul miop, din lipsa banilor, ducând o viaţă mai puţin decentă din punct de vedere financiar şi studiind într-un liceu obişnuit. Aspectul fizic de asemenea îi deosebeşte: Holden este frumos şi carismatic, dar adolescentul lui Eliade este slab, miop şi pistruiat. Primul are succes la fete, chiar dacă din cauza ciudățeniilor caracteristice nu este agreat de mamele acestora, pe când adolescentul suferă de insucces, din cauza urâţeniei, crede el. Pe de altă parte, Holden nu are prieteni de vârsta sa, îşi dispreţuieşte colegii, deoarece acestia sunt superficiali şi snobi, pe când adolescentul miop dispune de şansa de a avea prieteni cu care discută despre pasiuni comune, relaţiile cu colegii de şcoală rămânând totuși destul de distante.

Cele câteva zile din viaţa lui Holden Caulfield ne prezintă un adolescent care încearcă să se opună pragmatismului maturilor, falsităţii şi făţărniciei lumii din jur, oscilând mereu între ceea ce ar trebui să facă şi ceea ce simte el că este corect. Într-o societate americană postbelică, în care ceea ce este „moral” a devenit ceea ce este „normal” şi ceea ce „trebuie să fie făcut”, Holden nu îşi găseşte locul. Convingerile sale se bazează în primul rând pe propria lui conştiinţă morală, permanent problematică şi diferită de morala socială. Are un dar aparte de a observa oamenii din jur, înţelege de ce aceștia reacţionează într-un anumit fel în diferite circumstanţe, înţelege şi analizează emoţiile umane, fiind dotat cu o sensibilitate aparte. Consideră că şcoala este un spaţiu de recluziune, de înăbuşire a personalităţii. Rămâne dezamăgit de profesorul pe care îl preţuia, iar şcoala ca instituţie nu reuşeşte să ia locul părinţilor, de aceea se distanţează de ea. Respectiv, pică la mai multe materii. Singura la care trece şi la care avea mare talent, era literatura.

Împătimit de lecturi literare de o mare diversitate şi profunzime este şi personajul din Romanul adolescentului miop, ,una din cele mai surprinzătoare scrieri memorialistice ale lui Mircea Eliade, aceea de formare individuală, a şcolarităţii, cu idealurile, neîmplinirile şi ezitările ei” (Gheorghiu, 2015, p. 128). Insuccesul şcolar îl urmăreşte şi pe acesta. Motivele acestui eşec sunt simple şi liber consimţite: „Am rămas corigent, pentru că am vrut eu; sau, mai exact, nu am promovat, pentru că nu am vrut". Profesorul de matematică, Vanciu, anunţă că elevii cu note necorespunzătoare, având calificativul „insuficient”, pot să-şi corecteze notele peste trei zile. Adolescentul decide, împărtăşind cu voce tare: ,-- În noaptea asta nu se doarme, băieţi!” El îşi organizează minuţios timpul de lucru în cele trei zile: „,- Mă apuc să învăţ la două. Lucrez până la zece noaptea. Mănânc, mă culc, mă scol la două. Lucrez până mâine dimineaţă, apoi repet operaţia de două ori. [...]. În trei zile învăţ ce n-am învăţat un an şi scap..." Însă diferiţi factori îl sustrag de la studiu, proces destul de anevoios: „la patru şi jumătate m-am dus să fac duşul rece; la cinci şi jumătate $m$-am convins că sufăr de foame şi $m$-am coborât să mănânc; la şase jumătate am citit o revistă; la şapte mi-a fost sete, la șapte 
şi un sfert mi s-a rupt creionul, la şapte jumătate am devenit melancolic auzind ciripitul paserilor, la opt $\mathrm{m}$-am socotit persecutat, la opt şi un sfert am aprins lampa..." Elevul corigent trăieşte intens scurgerea clipelor, astfel încât observaţia trăirilor devine mai amănunţită. În final, el renunţă să mai înveţe, considerând că renunţarea este soluţia cea mai bună şi dacă va fi lăsat corigent, va avea destulă vreme la vară să înveţe. În concluzie, protagonistul romanului menţionează: „Nu sunt decât un adolescent ca şi toţi ceilalţi”. Este totuşi altfel pentru că el este cel care judecă situaţia, se judecă pe sine, este extrem de sincer cu privire la ceea ce i se întâmplă, la sentimentele care-l încearcă.

Împărtăşim opinia exegeţilor care afirmă că cele două personaje sunt autobiografice. Ambii adolescenţi sunt dezvoltaţi slab fizic, se află în perioada maturizării, la vârsta critică a nesiguranţelor şi căutărilor, trec prin experienţe erotice, se revoltă împotriva lumii adulţilor şi visează să schimbe societatea. Ambii au probleme la şcoală, trecând prin experienţa corigenţelor nu pentru că nu ar fi inteligenţi, ci pentru că au alte preocupări sau resping şcoala în semn de revoltă. Relaţiile dintre ei şi colegii de şcoală sunt reci şi distante.

La Mircea Eliade eroul este ,un adolescent, care simte cum depăşeşte adolescenţa, e sfârşit de melancolie... şi, totodată, e nerăbdător să se vadă cât mai repede eliberat de ea, ca să-şi poată începe ,,adevărata viaţă”. Tânărul susţine bacalaureatul şi se întreabă: „Cine ştie ce viaţă începe în zilele acestea de toamnă, când eu mă simt atât de schimbat, de străin, şi mă simt ispitit să plâng, să alerg, să râd?... Nu vreau să mă gândesc la Universitate. Caietul acesta e încă un caiet de adolescent. Mai vreau să scriu numai câteva pagini, şi apoi să-1 sfârşesc, pentru totdeauna. Cine ar putea înţelege tristeţea sălbatică a acestui sfârşit pentru totdeauna.... O viaţă se închide. Voi răsfoi mai târziu caietul şi, poate, nu-1 voi răsfoi - ca până acum - singur...Scriu cu greu. Mă simt furat de noi desfătări, de gânduri noi: Universitatea... Şi mă simt încă legat de adolescenţa mea, de acel roman pe care nu l-am scris". Este descrisă perioada în care eroul se caută pe sine, încercând să răspundă la o serie de întrebări privind propria condiţie spirituală.

Holden Caulfield este băiatul speriat de faptul că se maturizează, aflat într-o dilemă între lumea inocenţei, a copilăriei şi cea a adulţilor plină de compromisuri, ipocrizie, conformism, minciună. Îi mărturiseşte lui Phoebe că își tot imaginează „o mulţime de copii care joacă un joc într-un lan de secară. Mii de copilaşi şi nimeni prin preajmă - nimeni mare, vreau să spun - în afară de mine. Şi eu stau în picioare pe buza unei stânci scrântite. Ce am de făcut, trebuie să prind pe oricine ar trece dincolo de stâncă. Adică, dacă aleargă şi nu se uită pe unde merg, trebuie să apar de undeva şi să îi prind. Asta-i tot ce aş face toată ziua. Aş sta de veghe în lanul de secară şi-atât. Ştiu că-i o nebunie, dar e singurul lucru pe care mi-ar plăcea cu adevărat să-1 fac. E o nebunie, ştiu”. Semnificaţia acestui fragment, dar şi a titlului de altfel, este una mult mai profundă. Holden ar vrea să-i salveze pe copii de maturizare, 
lanul de secară reprezentând copilăria pură, nevinovată, ludică. Dincolo de „stânca scrântită” se află lumea superficială, ipocrită, vulgară a adulţilor.

Am putea concluziona că în întreg parcursul acțiunii, Holden şi Mircea trăiesc dilemele acestei etape a vieţii, nevoiţi fiind să păşească din adolescență în lumea pragmatică a maturilor. Romanele lui J. D. Salinger şi Mircea Eliade redau experienţe spirituale, trăite de tinerii aflaţi în lungul proces al iniţierii, prin rătăciri și căutări, când adevăratele dimensiuni spirituale sunt abia intuite. Cei doi eroi emblematici ajută receptorul să perceapă profund lumea adolescenţilor, diferitele tipuri de comportamente şi caractere adolescentine, problemele cu care tinerii se confruntă în încercarea de a percepe lumea, și de a-i da semnificații, din cu totul alte perspective.

\section{Referințe bibliografice:}

1. BUZZ... littéraire. La littérature nouvelle génération, de bouche-à-oreille. (en ligne, consultat pe 25/09/2021). L'Attrape-coeurs de J.D. Salinger: A quoi tient la magie d'Holden Caulfield?

2. ELIADE, Mircea. Romanul adolescentului miop. București, Cartex, 2000.

3. GHEORGHIU, Mihai. Reversul istoriei. Eseu despre opera lui Mircea Eliade. București, Humanitas, 2015.

4. SALINGGER, Jerome. De veghe în lanul de secară. Iași, Polirom, 2011. 1998.

5. SIMION, Eugen. Scriitori români de azi. vol. IV, Chişinău, Editura Litera,

6. J. D. Salinger, scriitorul care și-a detestat propria faimă, 30 ianuarie 2010, Fl. Ciuverca, Evenimentul zilei

7. TURIN, Joëlle. La littérature de jeunesse et les adolescents. BBF, 2003, nr. 3, p. 43-50. 